DOI: https://doi.org/10.31874/2309-1606-2020-26-1-9

УДК 37.013.73:168.522(477)

Катерина Гончаренко

\title{
Коли гуманітарій плакав або Криза гуманітарної освіти в Україні: симптоми і шляхи лікування
}

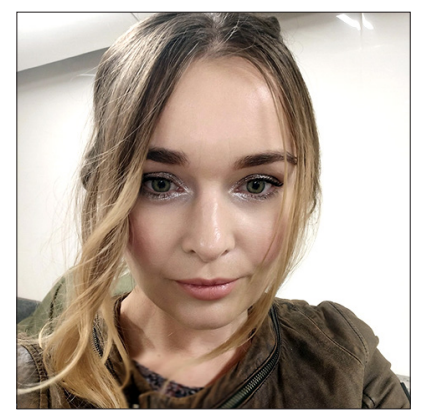

Дана стаття, можливо, геть позбавлена академічного пафосу та сповнена повсякденною іронією, але такий підхід, напевне, можна обгрунтувати тією ситуацією, яка на сьогоднішній день склалася в освітньому просторі України. Сама ж ситуація є настільки кричущою, що не викликає жодного бажання говорити «взірцевою мовою» високопосадовців та користуватися розлогими конструктами словоблудства на кшталт «світлого майбутнього» нашої освіти. За цих умов в даній статті здійснено спробу проаналізувати окремі проблеми, які існують в системі гуманітарної освіти України. Надано оцінку освітній стратегії країни (якщо вона взагалі існує) як суцільному «експериментаріуму», який грунтується на безперервному випробуванні на українській системі освіти різноманітних освітніх стратегій світу та в якому «піддослідними звірятами» виявляються діти та педагоги. Подібні експерименти навіть в експериментальній соціології чи психології називають «нелюдськими». Адже як тільки «наша» система освіти приймає нову стратегію, невдовзі з'являється черговий Міністр освіти зі своїми іншими нововведеннями та власним баченням ситуації; виявляється, що в цій стратегії відсутні або логіка, або належний взаємозв'язок між вищою та середньою школами; виявляється, що для вирішення мало не усіх проблем системи освіти заплановано зниження рівня державного фінансування гуманітарного блоку освіти та його знецінення, яке може призвести у не такій $i$ далекій перспективі до культурної деградації не лише освітньої сфери, але й українського суспільства. На останньому у статті акцентовано особливу увагу. Оскільки саме гуманітарна освіта, і ті ж таки гуманітарії, в будь-які часи, в будь-якій країні були провідниками суспільного та культурного розвитку, а їхній суспільний статус слугував показником рівня такого розвитку в цілому. Мета та завдання дослідження полягають у окресленні та аналізі гострих проблем, які існують на сьогоднішній день в області гуманітарної освіти та які спричиняють симптоматику їі «хвороби».

Ключові слова: криза системи освіти, освітня стратегія країни, гуманітарна освіти, гуманітарій, суспільний і культурний розвиток, освітні експерименти, експериментаріум. 


\section{Вступ}

Мабуть, досить очевидною з назви даного дослідження є алюзія на роботу Ірвіна Ялома «Коли Ніцше плакав» [Ялом 1992]. Якщо пригадати сюжет, то вочевидь перед нами постануть головні герої з їх копанням в проблемах, що виявляються не такими вже й вигаданими, їх спроби вирішити проблеми в умовах, коли старі прийоми вже більше не діють та не $є$ ефективними, їх гра в шахи та намагання осягнути гру, в масштабах якої вони є лише фігурами на шахівниці. Звісно, що нас не зовсім цікавить психоаналітична канва даної роботи, власне як і ряд інших запитань, які виринають з неї: більш цінним для нас є аналогія Ніцше (як центральної фігури в роботі Ялома [1992]) з гуманітарієм та з'ясування проблем, чому ж він плаче, що відбувається в той час, коли він плаче та чи можна йому якось зарадити. Відповіді на ці запитання ми будемо шукати в реаліях нашого українського освітнього простору, а точніше в системі освіти: в її гуманітарному секторі, для якого сам «гуманітарій» виявляється піддослідною мишею, до якої невпинно застосовують різноманітні експериментальні підходи. Сам же гуманітарій, у всій цій сазі, виявляється слабким, але й сильним одночасно: адже лише від нього самого залежить його подальше існування.

Як показує нам історичний досвід, майже кожна історична епоха була причетна до всіх тих змін, які відбувалися в освіті. Висуваючи свої вимоги, ставлячи свої умови та свої маркери задоволення/незадоволення станом освіти, вона демонструвала специфічні та яскраво виражені характеристики. Не є винятком і XXI ст. На сьогоднішній день «загальні проблеми сучасності, які впливають [на занепад освіти] - швидкі політичні, соціальні, економічні, культурні зміни, які перешкоджають створенню проекту майбутнього на довгу перспективу, зміна антропологічних принципів культури (поширення ідеї трансгуманізму, постлюдства, кінця людської винятковості), зникнення сталих ідентичностей, конфлікт інтерпретацій та панування постправди» [Шевчук 2020: 18].

Але, якщо в історії ми можемо фіксувати лише факти звершення, то сьогодення, що наскрізь пронизане ультрашвидкісними змінами та хаотичністю в прийнятті тих чи інших експериментальних освітніх програм, не дозволяє нам викристалізувати повноцінну картину, але схиляє до аналізу тих фактів, що вже є усталеними. Звісно, кожен історичний період маркується своїми особливостями, специфічними настроями та зростаючою невідповідністю старих «працюючих схем» у тій чи іншій галузі, тому не $є$ винятком і освіта, яка в залежності від епохи вимагає зміни освітньої парадигми. Посилення потреби у знаннях та вміннях, які б відповідали тенденціям розвитку суспільних процесів, лише посилює нові вимоги. Свого часу Еріх Фром [Фромм 2006] досить влучно окреслив коло рис, 
що спричиняють необхідність змін освітніх стандартів. Зокрема, саме у фромівських «пропозиціях» необхідності освітньої динаміки знаходимо, що над людиною нависає «імператив виживання» та відповідальності за подальший розвиток; що постіндустріальний світ вимагає гнучкості мислення та сприйняття світу; що освіта є джерелом до множинності палітри прийняття рішень (політичних, соціальних еtс.); що рівень розвитку держави суцільно залежить від конкурентоспроможності їі фахівців. Таким чином, можна вважати, що необхідність змін $є$ очевидною та обгрунтованою. Але все ж чи можна вважати все те, що відбувається в нашій системі освіти, таким, що працює саме на користь та благо людини, держави та її розвитку? Насамперед, можливі відповіді на дане запитання варто пошукати в тій освітній сфері, яку прийнято називати гуманітарною, та 3-поміж тих, кого характеризують гуманітаріями. Адже саме останні, поруч з винахідниками ядерної бомби і експериментаторами в області генної інженерії, несуть неабияку відповідальність за те, що відбулося чи відбувається в сучасному світі. Саме на плечі гуманітаріїв покладається відповідальність, від якої залежить і те, наскільки люди готові приймати факт наявності різних думок, позицій, і те, наскільки їм вдалося вплинути на формування критичного ставлення до одержуваної інформації в суспільстві, що $є$ вкрай актуальним на сьогодні.

\section{Точка-нуль освітнього експериментаріуму}

Чи є правдивим твердження: «Добре там, де нас немає»? У нашому українському середовищі дотепер існує думка, що переважна більшість явищ, які відбуваються на Заході, або хоч би де, носять виключно позитивний характер і $є$ ідеалом, про який Україна може лише мріяти. Це знову ж таки і якісна медицина, і краща екологія, і висококваліфіковані фахівці, і розмір зарплатні, який в рази перевищує межі уявного, і можна не працювати, але отримувати дотацію держави (бути на державному утриманні як, наприклад, це відбувається в Америці) та інше. Звісно, що для багатьох це може бути підставою для мрії та критики наявного у нашій країні. Спостерігаючи збоку за тими тенденціями, які відбуваються на Заході, більшість людей характеризує нашу країну як відсталу, консервативну, традиційну, таку, що неспроможна на позитивні зміни та в якій «все погано». Ця ситуація нагадує висловлювання Олександра Сергійовича Грибоєдова з його «Горя з розуму»: «Добре там, де нас нема». Спробуємо це розглянути на прикладі переходу від «радянської» системи освіти до «європейсько-інтегрованої».

Вже тривалий час (і сьогодення не є виключенням) в Україні дуже активно відбувається процес реформування майже всіх сфер буття людини, зокрема й сфери освіти. У зв'язку з цим у нашому суспільстві сформу- 
валася стійка думка, що саме попередня освітня програма - це джерело всіх негараздів та нещасть. I власне тому, їі не просто варто замінити, але й додати нововведень, які фактично наявні вже десь, які кимось вже випробувано. Якщо слідувати розповідям, переказам та історіям про колишню освіту, то існує низка стереотипів, які полягають в тому, що вона носила характер жорстокого «муштрування» та «натаскування», будувалася на «зазубрюванні» наукових фактів з того чи іншого предмету, жорсткій, суворій дисципліні, яка не дозволяла вільно розвиватися дитині, а також не допускала вільнодумства та нового погляду (це виражалося в неможливості самостійно обирати школу, в яку ходити; предмети, які вчити; спеціальність, яку обирати після закінчення школи - все це визначалося або ж освітньою програмою, або вчителями/батьками). Освіта була спрямована на підготовку масиву фахівців робітничих професій, а тому у ній начебто не залишалося місця таким явищам, як «креативність», «творче мислення», etc...etc зі всього того, що зараз намагаються «прищеплювати».

Однак, існує й інша сторона медалі. По факту, в колишній школі дітям давалися основи різних наук, при чому навчання здійснювалося на високому рівні. Прикладом може бути спілкування з людьми похилого віку, які навчалися в школі «того кшталту» та в свої 80 років можуть згадати матеріал шкільної освіти. (Тут варто зазначити, що формування освітнього індексу, або рівня освіченості населення, зокрема, міжнародного Education Index ${ }^{1}$ включає до свого статистичного розгляду загальну кількість населення, що отримує освіту, а також рівень грамотності дорослого населення). Загальне вивчення всіх цих наук давало дітям уявлення про те, що кожна наука має своє рішення тієї чи іншої проблеми, при цьому не применшуючи значення кожної з них. На основі цього діти могли вирішувати, яка сфера діяльності (область науки) є їм близькою, а яка ні. Коли обиралася якась сфера поглибленого навчання, дитина в межах цієї науки могла не просто нарощувати свої знання, але й проявляти творчість, задіювати новаторський підхід та включати свою уяву для того, аби згенерувати нові ідеї/відкриття та шляхи вирішення різноманітних проблематик. Підтвердженням цього можуть бути ряд відкриттів (навіть світового рівня) тих людей, які навчалися того часу. Згадаймо, хоча б Ландау, Павлова, Сікорського, Амосова, Довженка чи наближених до нашого часу Мамута, Линів, Левчіна, сестер Музичук... I цей перелік не $є$ вичерпним.

\footnotetext{
${ }^{1}$ Education Index (URL: http://hdr.undp.org/en/content/education-index)- міжнародний освітній індекс. Існує щорічне соціологічне дослідження ООН - індекс людського розвитку, який включає в себе три головних компоненти: освітній індекс, індекс ВВП та індекс тривалості життя. У цій трискладовій системі освітній індекс відіграє значку роль, оскільки саме він $є$ ключовим фактором при встановленні рівня розвитку країни.
} 
Ми повинні констатувати той факт, що в цій системі освіти були присутні як позитивні, так і негативні моменти; хоча мала місце і свого роду креативність, але вона стосувалася/проявлялася в конкретній галузі. I тому не можна говорити, що все старе варто відкинути і цілком орієнтуватися на «насаджування» нового, як власне не можна і навпаки. Зокрема, «питання про зміну чи трансформацію університету стосується питання погодження традиції та інновації в університеті, знаходження балансу між збереженням ним зв'язку із минулим і сталою системою академічних цінностей, з одного боку, та пристосуванням до вимог часу і необхідністю коригування візї̈ власного майбутнього, з іншого» [Шевчук 2020: 19].

Тут слід пригадати не лише слова Тараса Шевченка, який говорив: «Учитесь, читайте, і чужому научайтесь, й свого не цурайтесь», але й зауважити з позиції сучасного філософа політики - Ноама Хомського, який вважає, що будь-яка акція, дія, реформа приречена на поразку, якщо вона виходить лише з цілковитої критики попереднього досвіду [Хомский 2002]. Доповнити дану позицію також можна висловлюванням сучасного філософа Славоя Жижека: «Наразі нам потрібна конструктивна критика системи, але не в якості своєрідної інтелектуальної моди, а саме як інструменту для пояснення та зміни реальності» [Жижек 2012].

Якщо розглядати колишню систему української освіти, то вона формувала такого учня, який був компетентним (поглиблено зануреним) у якусь окрему науку (чи то мова, чи знання географії/хімії/математики тощо), що згодом створювало передумови для підготовки високоякісного фахівця в конкретній галузі знань, який реалізовував себе та своє «покликання» (вступ на філфак, фізмат, історичний тощо). Чого, власне, не скажеш про середньостатистичного учня, наприклад, школи у США, для якого важливим був завжди, наприклад, престиж університету (якщо дозволяли кошти) чи «знання всього й нічого», оскільки американська система освіти завжди виступала за «творчість», яка виражалася в певному довільному ставленні до шкільної освіти, яка в свою чергу не спрямоване на вивчення якоїсь з галузей знання, а більше орієнтована на вправність при екзаменаційному тестуванні чи вивченні-заучуванні конкретних відповідей на конкретні запитання. (Американська система освіти використовується задля прикладу, насамперед тому, що саме з неї привнесено чимало явищ в український освітній простір). Сьюзен Джекобі ${ }^{1}$, аналізуючи американську систему освіти, зазначає, що американці хворіють на «відсутність знання як такого» і способів подолання цієї епідемії поки не існує: «Спроби механічно покращити середній бал на стандартизованих екзаменах, нашпиговуючи учнів конкретними відповідями на конкретні

${ }^{1}$ Сьюзен Джекобі (Susan Jacoby) - репортерка «The Washington Post», авторка книги «Епоха нерозумності в Америці» («The Age of American Unreason»). 
Катерина Гончаренко. Коли гуманітарій плакав або Криза гуманітарної освіти в Україні...

запитання до конкретного тесту, справі не допоможуть» [Джекоби 2008]. Річард Хофстедтер ${ }^{1}$ пов'язує цю проблему з тим, що будучи однією з розвинених країн, Америка занадто рано перейшла від культури «друкованого слова» до «відео-культури», що в свою чергу призвело до того, що сучасна американська дитина майже не читає книг, а знаходиться в «цілодобовому інфотейменті» [Hofstadter 1963]. Наразі не будемо говорити про те, що саме з американських освітніх взірців ми отримали тестування і відповідно їхні неоднозначні наслідки для освіти.

Хоча наша сучасна освіта і $є$ такою, що успадкувала чимало підходів освітньо-програмного забезпечення саме з попередньої системи освіти, але наразі $є$ ще й такою, що орієнтована (або ж привносить/привнесла) західні зразки освітніх програм. Беззаперечно, ніхто не забороняє переймати якість взірці, програми, методики, і вони будуть більш чи менш ефективно діяти в наших реаліях. Та не варто забувати ще й про те, що спершу варто розуміти, наскільки такі програми будуть ефективними. А те, що ми можемо побачити на сьогоднішній день, можна вважати міксом різних підходів та методів навчання, у якому єдиною спільною рисою - основою коктейлю - $є$ орієнтованість на розвиток «чогось» (наприклад, тієї ж таки креативності) та набуття «компетентностей».

Якщо поглянути на вже згадуваний нами Education Index, який щорічно проводить дослідження сфери освіти на міжнародному рівні, то можна констатувати той факт, що з 2012 р. більшість провідних країн світу обрали орієнтиром освітньої політики відхід від «школи, яка вчить вчитися» до «мислимо креативно». За даними знову ж таки Education Index, не існує єдиного уявлення, яким чином має відбуватися даний перехід, але є чимало прикладів того, яким чином шкільна освіта проходить реформування в напрямку креативності. Кожна країна обирає для себе один з принципів чи проявів креативності та ним керується. Якщо, наприклад, розглянути США, то її шкільні реформи, або ж системи освіти, різні в кожному окремому штаті.

В системі освіти США, як ми вже зазначали вище, відсутня не лише єдина уніфікована освітня програма, але й відсутні будь-які орієнтири на результат та контроль за освітою (за даними Фонду Джона Локка аналітичного центру державної політики в Північній Кароліні [Stoops \& Hood 2016]). Результат, як вважають американські експерти з питань освіти, - більш головним визначають прагнення до освіти, яке всіляко заохочується. Одна з дослідниць освітньої стратегії Америки, А. Piплі (Amanda Ripley «The Smartest Kids in the World»), зазначає, що 60\%

\footnotetext{
${ }^{1}$ Річард Хофстедтер (Richard Hofstadter) - консенсус-історик, який в своїх дослідженнях акцентує увагу на політичній культурі, а не на повсякденних політичних діях. В роботі йде мова про його працю «Антиінтелектуалізм в житті Америки» («AntiIntellectualism in American Life»).
} 
оцінок школярів обгрунтовані не реальними знаннями чи навичками, а лише намаганнями/стараннями, які проявляють учні [Ripley 2013]. 3нову ж таки, це є результатом того хаосу, який присутній в цій системі. Не лише кожен штат, але й кожна окрема школа - це майже окрема освітня система. Чималу роль відіграє фінансування тієї чи іншої школи, а воно залежить від рівня успішності школярів та їх досягнень. Як вважає А. Ріплі ${ }^{1}$, більшість досягнень здобуваються в американських школах переважно за рахунок спортивних досягнень [Ripley 2013] (ні для кого не $є$ секретом, що в американських школах спорт виноситься майже на одне з перших місць).

В переважній меншості залишаються окремі школи/освітні заклади, які дійсно націлені на результат своїх учнів та які керуються сучасною стратегією «націленості на креативність». Ці школи в США називають «експериментальними школами». Наприклад, Columbus Signature Academy $^{2}$ що в Індіанополісі. Креативність проявляється в самому оформленні школи, яка суцільно збудована з прозорого скла, що дозволяє створити неформальний простір та замінити звичні, стандартні кабінети на студії, студійні зали, лабораторії, які є обладнаними відповідно до реалізації найрізноманітніших форм діяльності. Окрім цього, у кожного учня $\epsilon$ свій особистий ноутбук, що дозволяє освоювати і удосконалювати не лише комп'ютерну грамотність, але й провадити різні експерименти та дослідження. Також існує мережа шкіл Met - Metropolitan Regional Career And Technical Center ${ }^{3}$ В програму цих шкіл закладено те, що 2 рази на тиждень учні старшої школи, які обирають собі сферу інтересу та поглиблено вивчають їі, проходять практичне стажування на виробництві, а потім застосовують здобуті знання в своїй проектній роботі, результат якої презентують по закінченню роботи. Незалежна Summit School ${ }^{4}$ для дітей середньої школи, програма якої націлена на «мислити креативно, розмірковувати системно та працювати спільно» - розрахована на індивідуальний підхід до кожної дитини. В своїй основі ця програма переважно реалізується через позакласну освіту: заняття з робототехніки, програмування, драматичного мистецтва чи спорту тощо. Все це відбувається додатково до шкільної програми, і при цьому дозволяє в повній мірі задіяти принцип креативності. В той же час, на відміну від США, в Канаді існує єдина

\footnotetext{
${ }^{1}$ Аманда Ріплі (Amanda Ripley) - дослідниця та експертка освітнього простору. Географія її досліджень розповсюджується на переважну більшість розвинених країн $\epsilon_{\mathrm{B}-}$ ропи, а також на Америку. Мова йде про її роботу «Кращі в світі учні. Як навчити дитину вчитися» («The Smartest Kids in the World»).

${ }^{2}$ Columbus Signature Academy. - URL: https://www.csanewtech.com.

${ }^{3}$ The Met (Metropolitan Regional Career And Technical Center). - URL: https://educationreimagined.org/map/metropolitan-regional-career-and-technical-center/.

${ }^{4}$ Summit School. - URL: https://www.summitschool.com/.
} 
Катерина Гончаренко. Коли гуманітарій плакав або Криза гуманітарної освіти в Україні...

освітня програма країни, яка вже реалізується з 2014 року та в якій програмно закладено креативність, яка характеризується через здатність до інноваційності та винахідливості.

При цьому зазначимо, що сучасна система французької освіти, яка складалася протягом останніх двох століть і вважається однією з найбільш передових у світі, працює злагоджено, не ставить собі жодних світових орієнтирів та не обирає «курс на». Бюджет системи освіти щорічно становить понад 23\% бюджету країни ${ }^{1}$. А школярі, які закінчують школу, складають обов'язковий іспит з такої гуманітарної дисципліни як «філософія», і вважають, що їм це потрібно.

\section{Піксель 1}

Все те, що ми описували вище, власне підводить нас до однієї з проблем, яка сформувалася на сьогоднішній день в українській освіті. Для того, аби подолати «стару» систему освіти, Україна постійно обирає щоразу новий курс на існуючі в світі моделі та мало не почергово «приміряє» їх до власних реалій. Це призводить до того, що досить часто не існує навіть уявлення про те, над чим мають працювати педагоги чи що мають впроваджувати школи чи вищі освітні заклади, як наприклад, це відбувається з тим-таки курсом «на креативність» (креативне, творче мислення etc.) чи «на здобуття компетентностей»². Впровадження того, про що нерідко нема ані належного розуміння, ані хоча би точного опису, якщо вже не розлогого пояснення призводить, зокрема і серед іншого, до того, що в Україні відбувається жорстке розшарування і освітніх закладів, і дисциплін, які вивчаються (не важливо, це школа, чи 3 В0 (заклад вищої освіти)). Наприклад, нерозуміння того, що таке креативність, призводить до того, що окремі освітні заклади починають характеризувати себе як креативні, а відповідно вводять в навчальний процес все те, що американці характеризують як «аби хоч якось заохотити до навчання». Відповідно, на противагу їм, виникають «солідні» заклади, які в своїх навчальних планах скорочують години для гуманітарного блоку, оскільки він начебто більше звернений до креативності, творчості, мислення взагалі, тобто «абстрактно», і тому гуманітарні дисципліни починають виступати радше другорядним додатком до «важливих» і «конкретних» для вивчення курсів, предметів. Прикладом цього $є$ низка приватних шкіл,

\footnotetext{
${ }^{1}$ Сайт Міністерства вищої освіти і науки Франції (Ministere de l'Enseignement superieur et de la Recherche), URL: http://www.education.gouv.fr.

${ }^{2}$ Наскільки відмінні явища досить часто зводяться до одного визначення «креативність» див.: «Creative and critical thinking: Independent or overlapping components?» («Творче та критичне мислення: незалежні чи взаємопов'язані компоненти») [Wechsler et al. 2017].
} 
які діють саме за таким принципом. Поряд з цим існує ще одна проблема «ігор з нововведеннями». Ця проблема полягає у ставленні та оцінці школярами курсів та дисциплін. Якщо раніше лише у вищій школі був топ спеціальностей, то наразі у школярів також існує своя градація, яка, з одного боку, формується так званим «переліком для ЗНО», а з іншого, уявленням про «потрібне/непотрібне» (і чомусь до непотрібного потрапляють гуманітарні дисципліни). Наведемо приклад. 3-поміж 35-ти учнів 5-го класу («абстрактної» приватної школи), лише декілька вважають, що вивчення літератури $є$ необхідним. Всі ж інші говорять про те, що «мені це не знадобиться». Даний момент можна залишити без коментарів.

Якщо україниям сказати, що це «процес», то вони будуть сприймати це буквально. Новою віхою чи новим етапом формування сучасної парадигми освіти в Україні можна вважати всі ті трансформаційні зміни, які відбулися з моменту запровадження Болонської системи та так званої освітньої «євроінтеграції», інтеграції в європейський освітній простір, що запустило механізм з низки відповідних реакцій та перебудов. Відповідно до так званих європейських вимог, українська пост-радянська освіта жваво почала вирізняти все найбільш вартісне в західних зразках, що можна було би, чи радше - хотілося би, накласти на наш контекст, не враховуючи навіть того, чи накладається воно та чи діє.

Якщо ми поглянемо на основні установчі документи того періоду, коли починають формуватися подібні переорієнтації в освіті [Степко та ін., 2005], то можемо побачити, що з-поміж інших, головними було визначено принцип мобільності, багатообіцяючої і не зрозумілої «багатокультурності» з ї̈ апеляцією до вивчення, наприклад, іноземних мов, рівності прав та можливостей, просторову відкритість (зміцнення іноземних зв'язків), а також поліпшення рівня базової освіти з їі удосконаленням та адаптацією освітніх програм у відповідності до нових соціальних/економічних/etc. змін та формування дистанційних освітніх програм, курсів, осередків. Як ми можемо помітити - з того часу майже нічого не змінилося в намірах. Фактично, на сьогоднішній день ми маємо ті ж прагнення, лише з набутими вже проміжними результатами в ході проведення низки експериментів в площині освітнього простору.

3 моменту вибору вектору інтеграції в європейський освітній простір система вищої освіти прийняла ECTS (Європейську систему перезарахування кредитів - залікових одиниць трудомісткості), зробивши iї системою накопичення, здатною працювати в рамках концепції «навчання впродовж усього життя». Контроль за якістю освіти покладено на національні агентства, а заклади вищої освіти переорієнтовано на надання навичок та вмінь, а якщо бути більш точними та чесними, то на вміння формулювати навички та вміння в термінах освітніх програм. Адже, знову ж таки, як ми бачимо, за самою концепцією європейського 
Катерина Гончаренко. Коли гуманітарій плакав або Криза гуманітарної освіти в Україні...

стандарту, ці навички та вміння надаються для того, аби в подальшому студент застосував їх не лише як фахівець, але й використовував їх у повсякденній діяльності. В чому власне і $€$ певна затримка, оскільки все, що наразі відбувається в освіті, це досить часто не поєднувані між собою елементи, бо зміни, які націлені на один сегмент, не враховують взаємопов'язаних з ним елементів та тих змін, які відбуваються у них, причому нерідко за зовсім іншими критеріями. Тому досить часто все залишається або ж на папері, або ж відірваним від реальності. Досить наглядним є приклад зі студентською мобільністю. Адже у відповідності до норм та законодавчих актів, які дозволяють закордонні стажування, все ж існує низка неузгодженостей, які надто утруднюють їхню реалізацію: ті ж таки різноформатні освітні програми в Україні та за кордоном, система невідповідностей «з відривом/не-відривом) від виробництва та ін. Ба навіть всередині України академічна мобільність більш-менш запрацювала лише при переході з бакалаврата на магістратуру. Власне, як десять років тому, так і на сьогоднішній день це питання залишається відкритим. Єдине, що змінилося з того часу, це можливість самостійного пошуку різноманітних освітніх (грантових) програм студентами, залучення роботодавців до співпраці з вищими навчальними закладами - i те доволі боязке і епізодичне. Ахіллесовою п'ятою також можна вважати замовлення так званого «ринку праці», зокрема залучення роботодавців до участі у розробці стандартів вищої освіти, а також до їх співпрацю із ЗВО задля подальшого працевлаштування студентів. Хоча, як ми бачимо, найбільшими роботодавцями виявляються агенції на кшталт work. ua та rabota.ua, які пропонують здебільшого вакансії для некваліфікованих співробітників. Звісно, можна ще зробити поправку на можливу похибку на те, який це 3В0, якого рівня акредитації та форми власності.

Вищезазначені критичні зауваження у жодному випадку не виступають претензією на всеохоплюючий аналіз освітнього простору України, так як і не $є$ претензією на заперечення необхідності змін та тотальною критикою «Болонського процесу». Радше це визначення «точки-нуль», з якої розпочинається нова освітня парадигма в Україні та спроба демонстрації того, що багато які з проблем, які були на початку формування нової освітньої стратегії, не лише не вирішилися, але й посилися, а відповідні нормативні акти, що їх регулюють, мають низку недоліків та прогалин.

Зупинимося хоча б на деякий окремих аспектах, які, власне, виростають з Болонської системи та стосуються саме гуманітарної освіти. Як свого часу надто часто висловлювалися очільники 3В0, реформування системи вищої освіти України буде мати системний характер. 3 цим не можливо не погодитися, особливо це яскраво простежується останніми десятиліттями, а якщо бути більш точними, то декілька останніх років є визначальними для аналізу, коли влада змінюється настільки 
швидко, що зафіксувати, хто в профільному міністерстві за що відповідає та які чергові зміни вносяться в «систему» не вистачає терпіння, а оцінку ситуації вже не рятує ніяка іронія.

Ще з 2004 року, до підписання Міністром освіти і науки України Болонської декларації (Берген, травень 2005 року), в 26 провідних університетах країни почався так званий експеримент щодо впровадження кредитно-модульної системи організації навчального процесу як засобу реалізації основних принципів Європейської кредитно-трансферної системи. Начебто всі наміри були спрямовані на «благо» та на зміну парадигми навчання: на інноваційність змісту, технологій і методів освіти, орієнтацію на формування особистості студента/студентки, на розвиток його/ії здібностей діяти в умовах динамічних перетворень в економіці і суспільстві. Поряд з оновленням змісту і агрегацією дисциплін в навчальні плани були внесені вимірювання навчальних дисциплін, інших видів робіт студентів в кредитах трудомісткості; збільшено кількість годин на індивідуально-консультаційну роботу викладача зі студентом, на забезпечення модульного контролю; розроблені інформаційні пакети для підготовки фахівців (бакалаврів і магістрів) etc, etc. Продовжувати цей довжелезний список всіх можливих «спрямовано на» можна досить довго. Але у сухому залишку отримали значне зростання витрат часу викладачів не на методичну, а на звітну роботу, значну формалізацію обліку отриманих знань із не менш значною втратою контролю якості самих цих знань.

\section{Піксель 2}

Для нас же важливо побачити, що узагальнюючим визначенням для цієї системи може бути поняття «бухгалтерії»: підрахунки, цифри, години, кількості. 3 іншого боку, дійсно, система, яка пропонує впровадження технологій, нових навчальних методів $є$ прогресивною, однак, якщо держава пропонує таку систему освіти, то чому в державних 3 В0 ці так звані технології, нерідко відсутні й дотепер? Якщо викладач має проводити більше дистанційної роботи зі студентами, тоді чому програмне забезпечення такої роботи і досі є, як правило, справою ініціативи і особистої програмної вправності і матеріальних видатків викладача, а не забезпечується системно самим ЗВО? Але не це є вражаючим. Здавалося б, збільшення кількості годин на індивідуально-консультаційну роботу викладача зі студентом є неабияким «дарунком», особливо для гуманітарної освіти, яка власне і будується переважно на суб'єкт-суб'єктній роботі. Але при цьому ніхто не помітив, що ця індивідуальна робота має передбачати додаткові години роботи, які позначають окремий вид роботи, який передбачає індивідуальний графік навчання, і все це має 
складати суттєву частину офіційного індивідуального навантаження викладача, а не «навантажуватися» на нього понаднормово. Натомість, отримали суттєве скорочення аудиторних годин на гуманітарні дисципліни в усіх $3 В 0$ України. І от за рахунок такої «оптимізації» і було проведено новий розрахунок годин на гуманітарні дисципліни, який призвів до того, що з трьохрічного курсу «Історії філософії» у профільних філософів залишилося три семестри.

Ми ж повертаємося до логіки структури наших розмірковувань, а саме до гуманітарної освіти в Україні в її сьогоденні та спробуємо окреслити ті проблеми, від яких найбільше на нашу думку «плаче гуманітарій». Додатково зауважимо, що ми не претендуємо на всебічний аналіз ще й тому, що не можемо повною мірою відобразити стан всієї гуманітарної сфери країни, а лише переважно педагогічну освіту. А треба брати до уваги, що гуманітарний сектор - це система взаємопов'язаних між собою сфер, нехай і тимчасово нерідко штучно розірваних в наших українських реаліях.

\section{Піксель 3}

Один з парадоксів розвитку гуманітарного сектору в Україні пов'язаний з наступним. Не одна палка промова наших шановних політиків починається зі слів необхідності «розуміння самоцінності гуманітарної сфери», яка виконує людинотворчу функцію, виступає «життєвою базою», формує в людині «гуманістичні» (духовні/ціннісні) ідеали еtc...etc. Тому, нібито для гуманітарної політики розвиток освітньої сфери є пріоритетним та таким, що вимагає залучення, інвестування з боку держави, підтримки. I тому ми бачимо постійні зміни, які вносяться до Закону про освіту, а відповідно до всіх його розділів: дошкільна, загальна середня, позашкільна, професійно-технічна, вища, післядипломна освіта, а також аспірантура, докторантура та самоосвіта. Варто віддати належне: це дійсно ті щаблі, які є необхідними у формуванні освітньої системи, та не менш важливими сферами для формування гуманітарного блоку. Але, мабуть, не $є$ секретом, що для розвитку гуманітарного сектору у суспільстві необхідно, щоб сама система освіти мала потужний та розвинений гуманітарний блок: предмети, дисципліни, спеціальності etc. Навіщо? Насамперед тому, що це запорука «нашого світлого майбутнього» та його успішного впровадження, а також формування всіх тих загальнолюдських цінностей, опорою для яких виступає «гуманітарій звичайний».

Але що ж ми бачимо натомість в наших реаліях? На будь-якому 3 освітніх щаблів гуманітарний блок всіляко скорочується, а акценти переміщуються на вивчення прикладних та так званих «демократичних» дисциплін (наприклад, іноземні мови та щось з області релігійного чи 
статевого виховання). При цьому, якщо ми розглядаємо школу, то такі предмети як: «Етика», «Естетика», «Людина і світ» чи «Художня культура» - в більшості державних шкіл зводяться до одного семестру навчання і вивчаюся блоками. Якщо ми поглянемо на університетські реалії, то замість трьох років вивчення нормативного курсу, необхідного для фаху, ми отримуємо скорочену півторарічну версію на тему. I тут мова не йде про оцінку стану справ, ніхто не намагається виміряти це через дефініції «добре» чи «погано», мова йде про те, що в результаті цього, студент-«суспільствознавець» вчить інформатику довше, аніж фахові дисципліни. Справа в тому, що той таки студент-«суспільствознавець», який приходить на практику в школу, проводить заняття з суміжних дисциплін, наприклад, з історії України. Чи є ця ситуація адекватною? $\mathrm{Hi!}$ Чи відповідає вона тим зразкам та ідеалам, до яких ми прагнемо? Hi! Чи є це світовою тенденцією? Маємо надію, що ні.

\section{Піксель 4}

Розірваність між шкільною освітою та університетською або «забудьте все, чого вас вчили в школі». Особливо розрив відчувається у формуванні уявлень про університет, як наступний крок у навчанні, наступний освітній щабель, що $є$ необхідним після закінчення школи, як в якості продовження освітнього процесу, так і задля самовдосконалення та зрощування рівня самосвідомості. Не дарма ж «Вищою освітою тому варто називати ту системну освіту, яка сама починає продукувати нові знання, і яку може організовано надавати суспільство особистостям» [Бойченко 2020: 70].

Від того, яким чином формується підготовка в школі до «випуску», складається враження, що від дітей просто хочуть позбутися, а останні, в свою чергу, виявляються не готовими до того, що на них чекає, або ж все те знання, яке вони отримали, мало в чому їм допомагає для отримання вищої освіти. Доречним в даному ключі $є$ постать Івана Ілліча та його заклики до «знешколення суспільства». Звісно, це радше іронія, але всі ті недоліки, які він вбачає в шкільній освіті, є присутніми наразі - і не лише в Україні, а багато де у світі. Звернемося знову ж таки до згадуваного нами Еріха Фромма, який в роботі «Мати чи бути?» зазначає: «Школи - це фабрики, на яких виробляються пакети готових знань, хоча вчителі щиро думають, що знайомлять учнів з високими досягненнями людського духу. Безліч коледжів відмінно вміють підживлювати ці ілюзії. Вони примудряються запропонувати студентам «гігантські бутерброди» (з різних областей знання), від яких студент може відкусити шматочок то в одному, то в іншому місці, причому його нібито стимулюють до вільного вибору теми, не наполягають на жодному підручнику та інше» [Фромм 1998: 68]. 


\section{Піксель 5}

Однією з останніх тенденцій, яка з'явилася щодо освіти в українському інформаційному просторі, це спроби дискредитації необхідності університетської, або як її полюбляють називати журналісти - «затхлої академічної освіти» [Саламанюк 2013] та виведення на перший план необхідності/важливості всіляких індивідуальних і приватних освітніх курсів. Зокрема, щодо останніх, то лунає чимало думок, по-перше, що вони надають більш якісну освіту, таку, яка необхідна сучасному роботодавцю, а по-друге, пропонують навички, які відповідають сучасному світу в надзвичайно короткі строки. Прикладом подібного може бути «справа пана Потапенка» [Крикуненко 2019] ${ }^{1}$, яку так жваво обговорювали в пресі та «інтелектуальних колах» на початку вересня 2019-го. Так, справді. Захопливою $є$ історія львівського хлопчини, який після закінчення школи повідомив батьків, що хоче закінчити курси IT і зразу працювати, адже вступ до університету забере купу часу і там його не навчать тому, чого потрібно. Згодом ця стаття обросла прикладами інших «геніальних» молодих людей, які ділилися досвідом на кшталт: «задва-місяці-закінчив(ла)-курси-і-вже-згодом-заробляв-мільйони». Захопливі історії, які можуть лягти в основу одного з бестселерів типу «Як стати мільйонером, не встаючи з ліжка». Щось на кшталт вітчизняних «клонів» Ілона Маска, «генія-самородка».

Але повернемося до головної лінії наших розмірковувань. Так, сучасність надзвичайно хвора тим, що кожен може стати експертом та виносити свою експертну оцінку щодо того, що є вартісним, а що низькоякісним. Не можливо не погодитися, що «подекуди суспільного успіху досягають ті, хто взагалі не мав причетності до вищої освіти в будь-яких iї формах» [Бойченко 2020: 70]. Але все ж таки. Якщо ми поглянемо на досвід більшості провідних європейських країн (власне, на ті, на які рівняються та які є «зразковими» флагманами освіти - Франція, Німеччина, Англія еtс.), то можемо побачити, що жодна з них не скасувала університетську освіту на користь якихось курсів. Більш того, університетська освіта залишається базовою, фундаментальною, тим грунтом, від якого залежить і подальший рівень заробітної платні, і рівень самого фахівця. А всі ті курси, які в подальшому людина буде отримувати, вона лише «нарощує» на базову освіту, немов на скелет м'язи. Але ніколи жодні курси не виступають базовою, грунтовною освітою вищого рівня. Це насамперед пов'язано з тим, що освіта, академічна освіта має цінність, значення як джерело фундаментальних знань і відповідно дає рівень, завдяки якому хтось може вважатися фахівцем. «До конститу-

\footnotetext{
${ }^{1}$ На цю тему було чимало публікацій (2019), в переліку літератури наводимо приклад однієї з них.
} 
тивних завдань університетської освіти має належати масштабність, концептуальність та фундаментальність отриманих студентами знань» [Бойченко 2020: 71]. На Заході людина, яка не має можливості отримати університетську освіту, закінчуючи освітні курси, розуміє, що їі робота буде менш оплачуваною.

Щодо українських реалій та критики академічної освіти. Чимало каміння летить на її адресу саме через те, що нібито у стінах освітніх установ дають застаріле знання, все розповідають надто «академічною» (не зрозумілою) мовою та лише марно відбирають час. Так, варто погодитися, що 3В0, який ще не повністю скотився до «розважального» рівня - це наче динозавр, який ще встояв перед всією цією культурою споживання. Але, знову ж таки. Такі динозаври - це, можливо, єдині осередки, де живе щось справжнє, ціннісне, вагоме (замість популярного, розважального, поверхневого). На нашу думку, всі ті заклики, які лунають як закиди в бік надмірного «академізму», це спроба зруйнувати останні стіни, які втримують суспільство від тотальної поверхневості та попсовості. Адже наше суспільство знаходиться саме за крок від цього.

В той момент, коли освіта перестала бути цінністю, а стала товаром, «продуктом споживання», ми вийшли на дорогу, яка веде лише вниз. Нічого тривалого, нічого ціннісного, ніяких цінностей! Еріх Фромм таки свого часу був занадто правим (хоча й говорив це ще у 19 ст.), що гаслом «істинних споживачів» $€$ «Все нове - прекрасне!» [Фромм 2005]. У наш час акцент перенесений на сам процес споживання, а не на збереження придбаного, і сьогодні людина купує, щоб незабаром викинути покупку. Будь то автомобіль, одяг або якась дрібничка типу диплому про освіту - покористувавшись своєю покупкою протягом деякого часу, людина втомлюється від неї і прагне позбутися від «старої» речі і купити останню модель. Хоча навіть в таких умовах ринку можлива й інша стратегія. «Підприємливість» університету повинна означати не лише здатність бути ефективним на ринку, ставлячи собі пріоритетною метою продаж своїх освітніх пропозицій, але передусім здатність університету поширювати свою традицію та систему цінностей, тим самим змінюючи суспільство відповідно до власних ідеалів. Іншими словами, «підприємливість» університету проявляється також в його своєрідній політиці» [Шевчук 2020: 29].

Придбання - тимчасове володіння і користування - викидання (або, якщо можливо, вигідний обмін на кращу модель) - нове придбання - таким $є$ порочне коло споживчого придбання, на думку класиків. Саме тому, враховуючи подібний підхід до освіти, не можливо не погодитися з сучасниками, які не лише обстоюють думку необхідності академічної освіти, але й обгрунтовують можливість співіснування різних форм вищої освіти. «У будь-якому разі, не варто боятися розмаїття закладів вищої освіти, які може представляти приватна сфера. Їх, як завжди, краще врегулює ринок, 
аніж будь-які наукові дослідження й політичні програми. Буде суспільний попит - буде й потреба на ту освіту, яку надаватимуть ці заклади. У будьякому разі справжні університети мають не стільки наздоганяти суспільний попит, скільки формувати його» [Бойченко 2020: 81].

\section{Замість висновку}

I все ж таки, коли плакав гуманітарій? Він плакав, коли 3-поміж 11-тикласників (випускників секції «філософії», «абстрактного»навчального закладу), жоден не обирає філософію в якості майбутнього фаху, і навіть більше, нічого, що може бути гуманітарним. I це не тому, що абітурієнтам це не цікаво, а тому що «Управління бізнесом - це забезпечене майбутнє». Саме це я почула у особистій розмові.

Він плакав, коли бачив, що переважна більшість студентів, педагогів-гуманітаріїв, ладні обрати «роботу» менеджера, аби лише «не бути посміховиськом», адже «вчитель - це один з перших персонажів будьяких анекдотів», який має і відповідне ставлення, і відповідну повагу, і відповідні матеріальні «ресурси» ${ }^{1}$ [Мірошнікова 2019], які постійно десь потрібно «віднаходить».

Він плакав, коли розумні, талановиті, освічені - «вмикають раціо» та «тікають» туди, де «нормально платять», де цінують знання, де знання варте та комусь потрібне, де поважають «Hongik Ingan» ${ }^{2}$. Коли черговий потужний мозок «втікає» до Польського ЗВО в пошуках «кращої долі» та перспектив. А якщо звернутися до цифр та статистики, то виявляється, що у 2017/2018 навчальному році ${ }^{3}$ за кордоном навчалося 77424 студенти, які закінчили українські школи [Стадний 2019]...

\section{Посилання:}

Бойченко, М. (2020). Природне право на вищу освіту, або Яких змін потребує сучасний університет, а що не має змінюватися ніколи. Quo vadis, Універсuтете? / За ред. Дм. Шевчука. Острог: Видавництво Національного університету «Острозька академія», 69-83.

Джекоби, С. (2008). Тупеющая Америка? Называйте меня снобом, но мы и вправду превратились в страну дураков. Мысль. Журнал украинского истеблишмента. 26 (3) URL: http://www.idea-magazine.com.ua/archive/10239/trands/10274.html.

\footnotetext{
${ }^{1}$ В переліку літератури наведено приклад статті «Як вчителю заробляти більше?» [Мірошнікова 2019]. Дана стаття, як і багато інших подібного кшталту, є досить показовою щодо матеріальних реалій педагога.

${ }^{2}$ «Hongik Ingan» - «освічена людина» - національний девіз в Південній Кореї. Англійською цей вислів перефразовано як: «Benefit Broadly in the Human World/Devotion to the Welfare of Humanity» («Перевага в людському світі / Відданість добробуту людства»).

3 Як зазначається в статті на яку ми посилаємося, щодо статистичних даних про кількість студентів, які навчаються за кордоном, то з моменту 18-го року їх поки немає, оскільки «статистичний збір даних у різних країнах триває різну кількість часу».
} 
Жижек, С. (2012). Ситуация совсем не безнадежная, вам надо набраться терпения. Афиша Daily. URL: https://daily.afisha.ru/archive/gorod/archive/filosof-slavojzhizhek-o-protestah-korrupcii-i-budushhem-rossii/.

Крикуненко, I. (2019). Університетський бунт. Мінливий ринок вносить корективи у попит на вищу освіту. HB digital. Журнал. URL: https://magazine.nv.ua/ukr/ journal/3402-journal-no-31/universitetskij-bunt.html.

Мірошнікова, А. (2019). Як вчителеві заробляти більше? Osvitoria. URL: https:// osvitoria.media/ru/experience/yak-vchytelyu-zaroblyaty-bilshe-2/.

Саламанюк, T. (2013). По той бік плагіату. SVoє. 2. URL: https://commons.com.ua/ru/ po-toj-bik-plagiatu/.

Стадний, Є. (2019). Українське студентство за кордоном: дані до 2017/18 навчального року. CEDOS. Аналітичний центр. URL: https://cedos.org.ua/uk/articles/ ukrainske-studentstvo-za-kordonom-dani-do-201718-navchalnoho-roku.

Степко, М. Ф. та ін. (упорядники) (2005). Основні засади розвитку вищої освіти України в контексті Болонського процесу. Документи і матеріали. Травень-грудень 2004 р. Ч. II. Тернопіль: Вид-во ім. В. Гнатюка.

Хомский, Н. (2002). Новый военный гуманизм. Уроки Косова / пер. с англ. Л. Е. Переяславцева. М.: Праксис.

Фромм, Э. (2006). Здоровое общество / пер. с англ.. М.: Наука.

Фромм, Э. (1998). Иметь или быть? / пер. с англ. Фромм, Э. Иметь или быть? Психоанализ и религия. Искусство любить. Киев: Ника-Центр.

Шевчук, Д. (2020). Сучасний університет: традиція, яка творить майбутнє. Quo vadis, Університете? / За ред. Дм. Шевчука. Острог: Видавництво Національного університету «Острозька академія», 17-32.

Ялом, И. (1992). Когда Ницше плакал. М.: Наука.

Hofstadter, R. (1963). Anti-Intellectualism in American Life. New York: Alfred A. Knopf.

LaGravenese, R. (2007). «Freedom Writers». In IMDb. URL: https://www.imdb.com/title/ tt0463998/?ref_=fn_al_tt_1.

La stratégie nationale de culture scientifique (2020). Ministere de l'Enseignement superieur et de la Recherche. URL: https://www.enseignementsup-recherche.gouv.fr/pid34393/ simplification-de-l-enseignement-superieur-et-de-la-recherche.html.

Pinchas, P. (2007). When Nietzsche Wept. In IMDb. URL: https://www.imdb.com/title/ tt0760188/.

Ripley, A. (2013). The Smartest Kids in the World and How They Got That Way. New York: Simon \& Schuster.

Stoops, T. \& Hood, J. (2016). Educational Freedom Works: Scholarly research shows gains from school choice and competition. John Locke Foundation's research. URL: https:// www.johnlocke.org/.

Wechsler, S. M., et al. (2017). Creative and critical thinking: Independent or overlapping components? In Thinking Skills and Creativity. December 2017. DOI: 10.1016/j. tsc.2017.12.003. URL: https://www.researchgate.net/publication/321897468_ Creative_and_critical_thinking_Independent_or_overlapping_components / link/5b2ed6e2aca2720785dfddcb/download.

\section{References.}

Boichenko, M. (2020). The natural right to higher education, or What changes a modern university needs and what should never change. In: Shevchuk D. (ed.) Quo vadis, Uni- 
versity? Ostrog: Natsional University «Ostroh Akademy» Publishing House, 69-83. [In Ukrainian].

Chomsky, N. (2002). New Military Humanism. Lessons from Kosovo. M.: Praksis. [In Russian].

Jakoby, S. (2008). The Dumbing of America? Call me a snob, but we really turned into a land of fools. Idea. Journal of the Ukrainian Establishment. 26 (3) URL: http://www. idea-magazine.com.ua/archive/10239/trands/10274.html. [In Russian].

Fromm, E. (1998). To Have or To Be? In: Fromm, E. To Have or To Be ? Psychoanalysis and Religion. The Art of Love. Kyiv: Nika-Tsentr. [In Russian].

Fromm, E. (2006). Healthy Society. M.: Nauka. [In Russian].

Hofstadter, R. (1963). Anti-Intellectualism in American Life. New York: Alfred A. Knopf.

Krikunenko, I. (2019). University riot. The changing market is making adjustments to the demand for higher education. In NV digital. Magazine. URL: https://magazine.nv.ua/ ukr/journal/3402-journal-no-31/universitetskij-bunt.html. [In Ukrainian].

La stratégie nationale de culture scientifique (2020). In Ministere de l'Enseignement superieur et de la Recherche. URL: https://www.enseignementsup-recherche.gouv.fr/ pid34393/simplification-de-l-enseignement-superieur-et-de-la-recherche.html

LaGravenese, R. (2007). Freedom Writers. In IMDb. URL: https://www.imdb.com/title/ tt0463998/?ref_=fn_al_tt_1.

Miroshnikova, A. (2019). How can a teacher earn more? In Osvitoria. URL: https://osvitoria.media/ru/experience/yak-vchytelyu-zaroblyaty-bilshe-2/. [In Russian].

Pinchas, P. (2007). When Nietzsche Wept. In IMDb. URL: https://www.imdb.com/title/ tt0760188/.

Ripley. A. (2013). The Smartest Kids in the World and How They Got That Way. New York: Simon \& Schuster.

Salamanyuk, T. (2013). On the other side of plagiarism. In SvoE. 2. URL: https://commons. com.ua/ru/po-toj-bik-plagiatu/. [In Ukrainian].

Shevchuk, D. (2020). Modern university: a tradition that creates the future. In: Shevchuk D. (ed.) Quo vadis, University? Ostrog: Natsional University «Ostroh Akademy» Publishing House, 17-32. [In Ukrainian].

Stadniy, E. (2019). Ukrainian students abroad: data for the $2017 / 18$ academic year. In CEDOS. Analytical center. URL: https://cedos.org.ua/uk/articles/ukrainske-studentstvo-za-kordonom-dani-do-201718-navchalnoho-roku. [In Ukrainian].

Stepko, M. F., et al. (ed.) (2005). Basic principles of development of higher education in Ukraine in the context of the Bologna process. Documents and materials. May-December 2004. Ch. II. Ternopil: V. Hnatiuk Publishing House. [In Ukrainian].

Stoops, T., \& Hood, J. (2016). Educational Freedom Works: Scholarly research shows gains from school choice and competition. In John Locke Foundation's research. URL: https://www.johnlocke.org/.

Wechsler, S. M., et al. (2017). Creative and critical thinking: Independent or overlapping components? In Thinking Skills and Creativity. December 2017. DOI: 10.1016/j. tsc.2017.12.003. URL: https://www.researchgate.net/publication/321897468_ Creative_and_critical_thinking_Independent_or_overlapping_components/ link/5b2ed6e2aca2720785dfddcb/download.

Yalom, I. (1992). When Nietzsche Wept. M.: Nauka. [In Russian]. 
Zhizhek, S. (2012). The situation is not at all hopeless, you need to be patient. Afisha Daily. URL: https://daily.afisha.ru/archive/gorod/archive/filosof-slavoj-zhizhek-o-protestah-korrupcii-i-budushhem-rossii/. [In Russian]

Katerina Honcharenko. When the humanities lecturer wept or Crisis of humanitarian education in Ukraine: symptoms and treatment options

This article may be completely devoid of academic pathos and full of everyday irony, but such an approach can probably be justified by the situation that has developed in the educational space of Ukraine for today. The situation itself is so glaring that it does not arouse any desire to speak in the "model lexicon" of high-ranking officials and to use extensive constructs of fornication such as the "bright future" of our education. Under these conditions, this article attempts to analyze some problems that exist in the system of humanitarian education in Ukraine. The country's educational strategy (if it exists at all) is assessed as a perpetual "experimentarium", which is based on continuous testing of existing in the world various educational strategies on the Ukrainian education system and in which children and teachers are "guinea pigs". Such experiments, even in experimental sociology or psychology, are called "inhuman". After all, as soon as "our" education system adopts a new strategy, the next Minister of Education will soon appear with his other innovations and his own vision of the situation; it turns out that this strategy lacks either logic or proper relationship between higher and secondary education; it turns out that in order to solve almost all the problems of the education system, it is planned to reduce the level of state funding of the humanitarian education unit and its devaluation, which may lead to cultural degradation not only in education but also in Ukrainian society. The latter focuses on special attention. Because it is the humanities education, and in particular humanities lecturers, at any time, in any country have been the leaders of social and cultural development and their social status served as an indicator of the level of such development in general. The purpose and objectives of the study are to outline and analyze the acute problems that exist today in the field of humanities education and which cause the symptoms of its "disease".

Key words: crisis of the education system, educational strategy of the country, humanitarian education, humanities lecturer, social and cultural development, educational experiments, experimentarium.

Екатерина Гончаренко. Когда гуманитарий плакал или Кризис гуманитарного образования в Украине: симптомы и пути лечения

Данная статья, возможно, напрочь лишена академического пафоса и полна повседневной иронией, но такой подход, наверное, можно обосновать той ситуацией, которая на сегодняшний день сложилась в образовательном пространстве Украины. Сама же ситуация является настолько вопиющей, что не вызывает никакого желания говорить на «образцовом языке» чиновников и пользоваться раскидистыми конструктами словоблудия вроде «светлого будущего» нашего образования. В этих условиях в данной статье 
предпринята попытка проанализировать отдельные проблемы, которые существуют в системе гуманитарного образования Украины. Дана оценка образовательной стратегии страны (если она вообще существует) как сплошному «экспериментариуму», основанному на непрерывном испытании на украинской системе образования различных образовательных стратегий мира и в котором подопытными кроликами оказываются дети и педагоги. Подобные эксперименты даже в экспериментальной социологии или психологии называют «нечеловеческими». Ведь как только «наша» система образования принимает новую стратегию, вскоре появляется очередной Министр образования со своими другими нововведениями и собственным видением ситуации; оказывается, что в этой стратегии отсутствуют или логика, или должная взаимосвязь между высшим и средним образованием; оказывается, что для решения почти всех проблем системы образования запланировано снижение уровня государственного финансирования гуманитарного блока образования и его обесценивание, которое может привести в не такой уж далекой перспективе к культурной деградации не только образовательной сферы, но и украинского общества. На последнем в статье акцентировано особое внимание. Поскольку именно гуманитарное образование, и те же гуманитарии, в любые времена, в любой стране были проводниками общественного и культурного развития, а их общественный статус служил показателем уровня такого развития в целом. Цель и задачи исследования заключаются в обрисовке и анализе острых проблем, которые существуют на сегодняшний день в области гуманитарного образования и вызывающие симптоматику ее «болезни».

Ключевые слова: кризис системы образования, образовательная стратегия страны, гуманитарная образования, гуманитарий, общественное и культурное развитие, образовательные эксперименты, экспериментариум.

Гончаренко Катерина Сергї̈вна, кандидат філософських наук, доцент кафедри філософії факультету філософії та суспільствознавства Національного педагогічного університету імені М.П. Драгоманова.

e-mail: agneshka13@gmail.com

https://orcid.org/0000-0003-1162-9464

Honcharenko Kateryna Serhiivna, Candidate of Philosophical Sciences, Associate Professor of the Department of Philosophy, Faculty of Philosophy and Social Sciences, Dragomanov National Pedagogical University.

e-mail: agneshka13@gmail.com

https://orcid.org/0000-0003-1162-9464 